\title{
Identifikasi Potensi dan Analisis Masalah Sumber Daya Perikanan di Kecamatan Nambo Kota Kendari Provinsi Sulawesi Tenggara
}

\author{
[Potential identification and analysis of fisheries problems in Nambo Subdistrict, \\ Kendari City, Southeast Sulawesi Province]
}

\author{
Nasriyah, Pigoselpi Anas \\ Sekolah Tinggi Perikanan, Jurusan Penyuluhan Perikanan \\ Jalan Cikaret Nomor 1Bogor 16001, Jawa Barat
}

Diterima: 1 Juni 2018; Disetujui: 10 Agustus 2018

\begin{abstract}
Abstrak
Tujuan ulasan studi literatur keanekaragaman hayati dan konservasi ikan air tawar ini adalah untuk mendalami keanekaragaman hayati ikan di perairan tawar dan masalah eksistensi sebagian spesiesnya yang mulai terancam punah, serta faktor kesalahan pengelolaaan yang terjadi. Strategi global yang ditawarkan dalam ulasan studi literatur ini didasarkan atas pemilihan langkah konservasi sebagai jawaban untuk mengatasi ancaman kepunahan tersebut. Konservasi adalah perlindungan dan pelestarian kehidupan akuatik yang penting dalam menata keseimbangan alam dan mendukung ketersediaan sumberdaya bagi generasi yang akan datang. Tercatat spesies ikan yang ada di Indonesia berjumlah 1193 spesies dan keanekaragaman spesies ikan air tawar Indonesia nomor tiga terkaya di dunia. Ikan endemik adalah ikan yang keberadaannya hanya ada pada satu tempat tertentu, dan tidak ada di tempat lain. Ikan endemik di Indonesia berjumlah sekitar 120 spesies.Ditinjau dari sudut iktiogeografis, ikan air tawar di Indonesia mendiami tiga daerah sebaran geografis (Paparan Sunda, Daerah Wallace, dan Paparan Sahul) yang dibatasi oleh dua garis maya: Garis Wallace dan Garis Weber. Menetapkan tujuan dan sasaran konservasi; Merancang langkah- langkah pelaksanaan; Menyiapkan sarana dan prasarana pendukung yang diperlukan; Menentukan kriteria atau tolok ukur keberhasilan konservasi; dan Memantau serta mengevaluasi hasil berdasarkan kriteria yang telah ditetapkan.
\end{abstract}

Kata penting: keanekaragaman hayati ikan; konservasi ikan; perairan tawar

\section{Abstract}

The purpose of this review was to study about fish biodiversity and fish conservation in inland waters and to examine the potensial problem how a lot of species become extinct; off course also by mismanagement decision. The global strategy on this problem is based on chossing conservation as an answer to overcome that extinct species. Conservation it self was a principal of how to protection and preservation an important aquatic life as a part of arranging the balance of nature; and how to support the availability of resourses for future generations. The total amount of species fish in Indonesian was 1.193, beside that the biodiversity of Indonesia was record as the third richest-diversity in the world. Endemic fish is an fish whose their existence or their life cycle only in specific environment. The amount of endemic fish in Indonesia was record reach around 120 species. As a reviewed by ichthyogeografic sides, fresh water fish in Indonesia is spread and inhabit in three geografic area, that is: Paparan Sunda, Wallace area, and Paparan Sahul; which is limited of two imagine line: Wallace Line dan Weber Line. The Conservation purpose and its target, consists of: design implementation steps, prepare the necessary facilities and infrastructure, determine the criteria and benchmarks of succed conservation; and monitoring evaluation based on the criteria.

Keywords: fish biodiversity; fish conservation; inland waters 


\section{Penulis korespondensi}

Pigoselpi Anas | pigoselpi.anas@gmail.com

\section{PENDAHULUAN}

Kementerian Kelautan dan Perikanan (KKP) telah menetapkan arah kebijakan dan strategi pembangunan kelautan dan perikanan melalui industrialisasi perikanan. Kebijakan ini bertujuan meningkatkan produktivitas dan nilai tambah produk serta meningkatkan produktivitas dan nilai tambah produk serta meningkatkan daya saing berbasis pengetahuan dan teknologi. Ada tujuh hal yang ingin dicapai dalam industrialisasi perikanan seperti peningkatan nilai tambah, peningkatan daya saing, modernisasi sistem produksi hulu dan hilir, penguatan pelaku industri perikanan, berbasis komoditas, wilayah dan sistem manajemen, berkelanjutan serta transformasi social (KementerianPPN/Bappenas 2016).

Dalam rangka pencapaian tujuan industrialisasi kelautan dan perikanan tentu peningkatan produksi tidak hanya sekedar berbasis kuantitas tetapi yang terpenting adalah kualitas produk. Kualitas produk perikanan akan terjamin jika pelaku utama menyadari etika bisnis yang memahami semakin baik kualitas maka semakin baik pula nilai yang akan diberikan seharusnya telah dapat menjadi prinsip dari pelaku utama. Sehingga keseimbangan teknologi dan bisnis perlu diperhatikan. Penyeimbangan ini belum akan terjadi tanpa adanya suatu kesadaran dari pelaku utama dan usaha tersebut, sehingga diperlukan suatu upaya menanamkan nilai pentingnya kualitas dalam suatu bisnis perikanan, sehingga dibutuhkan penyuluhan perikanan. Kesinergisan ketiga komponen ini yaitu teknologi, bisnis perikanan dan penyuluhan merupakan suatu kunci peningkatan produksi berkualitas dan keberlanjutan perikanan (Pusat Pelatihan dan Penyuluhan Kelautan danPerikanan 2018).

Dalam menjalankan kegiatan penyuluhan seorang penyuluh membutuhkan suatu data seta informasi yang sangat akurat baik data potensi wilayah maupun data kependudukan dan permasalahan yang ada di pelaku utama perikanan dan pelaku usaha perikanan (Amanah 2003).

Wilayah perairan Sulawesi Selatan memiliki sumberdaya ikan yang berlimpah dan beraneka ragam. Dari 
data statistik tahun 2007 menunjukkan bahwa terjadi peningkatan produksi dan jumlah nelayan untuk melakukan penangkapan jenis ikan ekonomis penting. Seiring dengan meningkatnya jumlah penduduk dan kebutuhan pangan dan gizi yang febih baik sangat memacu tingginya permintaan masyarakat pada kebutuhan konsumsi ikan. Permintaan ikan yang meningkat tentu berpengaruh positif bagi peningkatan pendapatan nelayan, namun perlu disadari bahwa peningkatan permintaan sumberdaya tersebut selalu diikuti tekanan untuk melakukan eksploitasi semakin intensif.

Sampai saat ini hasil tangkapan khususnya ikan kuwe (Carangidae sp.) di Sulawesi Selatan tetah mencapai 2,302.3 ton pada tahun 2007 (Tangke 2010).

Kawasan Kota Kendari lebih dari setengah luas wilayah yang memiliki 4 kecamatan ini digunakan sebagai lahan pertanian, dengan perikanan menjadi penyumbang terbesar. Nilainya mencapai Rp 235 miliar atau lebih dari seperlima total kegiatan ekonomi di tahun 2001. Dengan garis pantai tak kurang dari dari 85,8 kilometer, menyuguhkan potensi laut yang menjanjikan untuk usaha perikanan, apalagi Pulau Bungkoto berhadapan langsung dengan Laut Seram, Laut Maluku, Laut Arafura, dan Laut Flores yang dikenal kaya akan berbagai jenis ikan yang bernilai ekonomi tinggi seperti cakalang, layang, tengggiri, kembung, udang. Demikian halnya perikanan darat. Dari 380,25 hektar luas potensial budidaya tambak, masih $31,5 \%$ yang belum terjamah. Sementara budidaya kolam baru terolah $27,67 \%$ dari luas potensial sekitar 150 hektar (Dhakidae 2005).

Kawasan industrialisasi wilayah pesisir Kecamatan Nambo Kota Kendari mempunyai banyak potensi sumberdaya perikanan. Potensi sumberdaya perikanan yang ada sekarang dapat dipertahankan dan dikembangkan menjadi potensi pariwisata dan industri budidaya pantai. Kecamatan Nambo $\quad$ Terdapat 6 Kelurahan yang terdiri dari Kelurahan Bungkutoko memiliki hutan mangrove sekitar 2 ha untuk di kembangkan menjadi hutan mangrove wisata. Pantai Nambo dan Pulau Bungkutoko yang juga berpotensi untuk pengembangan pariwisata pantai masing-masing seluas 5 ha. Kegiatan lain yang dapat dikembangkan adalah usaha budidaya laut (mariculture). Usaha budidaya lainnya adalah budidaya pembesaran ikan kuwe yang cukup berkembang pesat di kelurahan sambuli, Tondonggeu dan Petoaha.

Tujuan penelitian ini adalah untuk mengidentifikasi potensi dan 
permasalahan sumberdaya perikanan yang meliputi sistem produksi perikanan, sistem usaha perikanan, dan sistem penyuluhan perikanan.

\section{BAHAN DAN METODA}

Bahan yang digunakan pada penelitian ini adalah lembar penilaian responden. Penelitian dilaksanakan tanggal 30 Oktober 2017 sampai dengan 28 November 2017 bertempat di Kecamatan Nambo Kota Kendari Provinsi Sulawesi Tenggara.

Data yang digunakan dalam pelaksanaan praktek keahlian adalah data primer dan data sekunder yang berhubungan dengan tujuan kegiatan praktek keahlian ini. Sumber untuk memperoleh data primer adalah semua yang tergabung dalam kelompok pembudidaya, penyuluh perikanan, pedagang, dan pihak yang mendukung kegiatan perikanan. Pengambilan data primer menggunakan metode Participatory Rural Appraisal (PRA), yaitu :

a. Pengamatan langsung

b. Wawancara semi struktur dengan:

- Kelompok nelayan, pembudidaya dan pengolah ikan.

- Pelaku utama (individu) nelayan, pembudidaya dan pengolah ikan.
- Tokoh Masyarakat.

Data sekunder didapatkan dari pengumpulan data dan informasi berupa dokumen wilayah, monografi dan data penunjang lainnya (Suryabrata, 2012). Penentuan jumlah sampel RTP atau pelaku utama tergantung pada jumlah populasi. Jika jumlah populasi $<100$, penentuan sampel akan dilakukan dengan teknik sensus, yaitu pengambilan data dari semua elemen/anggota dari suatu populasi. Jumlah populasi $>50-100$ responden 20 $30 \%$, penentuan sampel dilakukan dengan pendekatan purposive sampling, yaitu memilih responden baik individu maupun kelompok yang dinilai dapat mewakili dalam memberikan data dan informasi yang diperoleh selama praktek keahlian. Jumlah populasi $>100$, penentuan sampel dilakukan dengan menggunakan teknik penentuan sampel (Widodo, 2008).

Menurut Riduan (2005) cara menentukan besarannya ukuran sample memakai rumus slovin yaitu :

$$
\mathrm{n}=\frac{\mathrm{N}}{1+\mathrm{N}(\mathrm{e})^{2}}
$$

Ket :

$\mathrm{n}=$ ukuran sampel

$\mathrm{N}=$ Populasi

$e=$ Tingkat kesalahan $(5 \%-20 \%)$ 
HASIL DAN PEMBAHASAN

\section{Sumber daya Alam}

Kecamatan Nambo adalah salah satu kecamatan yang terletak di kota kendari Provinsi Sulawesi Tenggara dengan luas kecamatan Nambo 26,92 $\mathrm{km}^{2}$. Kecamatan Nambo terdiri dari 6 wilayah kelurahan yang terdiri dari kelurahan nambo, petoaha, tondonggeu, sambuli, Bungkutoko, dan kelurahan tobimeita

Batas wilayah kecamatan Nambo terdiri dari :

- Sebelah Utara: Kecamatan Kendari

- SebelahTimur: Kabupaten Konawe Selatan

- Sebelah Barat: Kecamatan Abeli

- Sebelah Selatan: Kabupaten Konawe Selatan

Kota Kendari terletak di jazirah tenggara Pulau Sulawesi secara geografis terletak di bagian Selatan Garis katulistiwa. Memanjang dari utara ke selatan di antar $2^{\circ} 45^{\prime}-6^{\circ} 15^{\prime}$ lintang selatan dan membentang dari barat ke timur di antara $120^{\circ} 45^{\prime}-124^{\circ}$ 30 ' bujur timur. Kota Kendari pada umumnya berombak sampai bergelombang dan berbukit. Ketinggian kota $3 \mathrm{~m}$, tertinggi $15 \mathrm{~m}$, rata-rata ketinggian $7 \mathrm{~m}$.

Menurut BPS kota kendari (2017), Wilayah kecamatan nambo hanya memiliki dua musim, yakni musim kemarau dan musim hujan. Menurut data yang ada di kecamatan nambo pada tahun 2017 terjadi sebanyak 205 hari hujan dengan rata-rata curah hujan 179 $\mathrm{mm}$, suhu rata-rata adalah 27,6 derajat celcius dengan suhu minimum adalah 24,8 derajat celcius dan maksimum adalah 31,8 derajat celcius. Kelembaban udara rata-rata 84 derajat celcius dengan suhu udara minimum 57 derajat celcius dan 98 derajat celcius.

\section{Sumber Daya Manusia}

Kecamatan Nambo tahun 2016 mempunyai penduduk sebesar 10.821 jiwa, jumlah penduduk laki-laki sebanyak 5.518 jiwa dan perempuan sejumlah 5.303 jiwa. Adapun kondisi bidang perikanan di Kecamatan Nambo terlihat dari jumlah Rumah Tangga Perikanan (RTP) baik RTP budidaya, RTP pengolah dan RTP nelayan dapat dilihat pada Tabel 1. Jumlah ini RTP $>100$ sehingga untuk menentukan jumlah sampel yang akan disurvay, menggunakan rumus Slovin. Hasil perhitungan menggunakan rumus slovin, maka didapatkan sampel responden sebesar 23,9 RTP atau digenapkan menjadi 24 RTP. Sampel terdiri dari tiga bidang perikanan. Sampel pelaku usaha perikanan dibidang penangkapan 13 orang, budidaya pembesaran ikan 10 orang dan 1 orang pengolah ikan. 


\section{Tabel 1. RTP Kecamatan Nambo}

\begin{tabular}{lccc}
\hline \multicolumn{1}{c}{ Desa / Kelurahan } & $\begin{array}{c}\text { RTP Budidaya } \\
\text { (orang) }\end{array}$ & $\begin{array}{c}\text { RTP Nelayan } \\
\text { (orang) }\end{array}$ & $\begin{array}{c}\text { RTP Pengolah } \\
\text { (orang) }\end{array}$ \\
\hline Tondonggeu & 45 & 36 & - \\
Sambuli & 87 & 94 & - \\
Petoaha & 90 & 110 & - \\
Bungkutoko & 41 & 46 & 1 \\
Tobimeita & - & - & - \\
Nambo & - & - & 1 \\
\hline Jumlah RTP & 263 & 286 & \\
\hline
\end{tabular}

Sumber Data: DKP, 2017

Pelaku utama perikanan (RTP) tersebar merata hampir di semua desa. Pelaku usaha perikanan ini yang mempunyai usaha sampingan seperti pedagang makanan dan minuman. Usaha tersebut sangat penting karena bisa menambah penghasilan. Kelurahan Nambo dan Tobimeita tidak terdapat pelaku utama perikanan karena kelurahan tersebut bukan wilayah pesisir dan mereka banyak yang berprofesi sebagai PNS dan petani jagung.

\section{Sistem Produksi Perikanan}

Sistem produksi perikanan di Kecamatan Nambo meliputi hasil dari kegiatan usaha yang dilakukan oleh pembudidaya, nelayan dan pengolah selama 1 siklus produksi, sehingga menghasilkan nilai produksi dan produktifitas hasil perikanan. Sistem usaha budidaya meliputi usaha pembesaran ikan kuwe di Kecamatan Nambo dilakukan di wadah keramba jaring tancap. Tahapan pembesaran ikan kuwe keramba jaring tancap sebagai berikut:

\section{a. Persiapan Wadah KJT}

Kontruksi untuk membuat keramba menggunakan bambu yang ditancapkan ke dasar perairan laut. Bambu sebagai kerangka waring dibuat sehingga membentuk petak keramba, kemudian waring diikatkan ke bambu dan bagian bawah waring diikatkan pemberat sehingga waring sampai ke dasar laut atau sesuai dengan kedalaman yang diinginkan. Ukuran 1 unit keramba tancap $4 \mathrm{~m}$ x 6 $\mathrm{m}$. Tinggi waring sebagai tempat pembesaran ikan kuwe mengalami tahap perkembangan dimana pada awalnya menggunakan waring yang tingginya sekitar $1 \mathrm{~m}$ dari permukaan air, ternyata hal ini menyebabkan ikan bisa lepas bila terjadi pasang. Sehingga untuk menghindari hal tersebut dibuat tinggi waring mencapai $2 \mathrm{~m}$ di atas permukaan 
perairan laut. Daya tahan waring tempat pembesaran ikan kuwe bisa mencapai 1 tahun, sehingga setiap 1 tahun dilakukan pergantian dan perbaikan kondisi. Keramba Jaring Tancap secara keseluruhan. Perbaikan yang berskala kecil dilakukan juga seperti perbaikan waring yang robek dan ikatan bambu yang sudah tidak kuat apabila dianggap perlu.

b. Penebaran Benih

Benih ikan kuwe yang ditebar oleh pembudidaya diperoleh dari Pantai Nambo. Penebaran benih dilakukan pada pagi hari untuk mencegah stress pada ikan yang diakibatkan peningkatan suhu. Ikan kuwe yang ditebar berukuran $6-8 \mathrm{~cm}$. Sebelum ikan ditebar dilakukan aklimatisasi suhu dan pengukuran salinitas perairan laut dengan cara menempatkan ikan kuwe ke dalam satu wadah/ baskom yang diisi dengan air laut.

c. Pemeliharaan

Pemeliharaan dilakukan selama 1012 bulan untuk mencapai ukuran konsumsi atau 1-1,5 kg/ekor. Selain memakan pakan alami, ikan diberi pakan (ikan rucah) 2 kali sehari tanpa dilakukan pemberian pakan buatan seperti pakan pellet, d. Pemberantasan Hama

Hama yang sering mengganggu yaitu munculnya tiram dan kerang kerangan yang melekat pada jaring sehingga dapat menimbulkan kerusakan pada jaring yang dapat menyebabkan ikan lolos atau keluar dari wadah keramba tersebut. Penanggulangan hama yang dilakukan oleh pembudidaya yaitu jika terjadi air laut surut dan ketinggian air mulai berkurang dilakukan pengecekan jaring dalam 1 bulan 2 kali agar dapat mengetahui munculnya hama tersebut sehingga dapat dilakukan pembuangan atau pembersihan pada jaring.

e. Pemanenan

Pemanenan dilakukan setelah ikan dipelihara selama 10-12 bulan. Pemanenan dilakukan pada pagi hari karena pada pagi hari air laut surut, pemanenan dilakukan oleh 2 tenaga kerja dengan cara panen total yaitu mengangkat jaring tersebut dengan cara mengeliling hingga ikan dapat berkumpul kemudian dimasukkan ke dalam ember. Ikan yang dipanen langsung ditempatkan di blong / basket yang diberikan balok es yang bertujuan teap menjaga kualitas dan mutu ikan, biasanya menghabiskan $2-5$ balok es. 
Usaha penangkapan ikan juga banyak terdapat di Kecamatan Nambo, yaitu penangkapan one day fishing, dalam melakukan penangkapan dilakukan menggunakan perahu bermesin dengan alat tangkap yang digunakan yaitu pancing ulur dan pancing rawe.

Adapun tahapan pada proses penangkapan ikan adalah sebagai berikut:

a. Persiapan alat tangkap dan kapal Persiapan alat tangkap dan kapal yang dilakukan sebelum berangkat melaut seperti memperbaiki pancing dan menyiapkan umpannya, memeriksa adanya kebocoran atau memperbaiki kapal dan mengecek mesin.

b. Persiapan input produksi

Persiapan input produksi yaitu mengisi bahan bakar untuk mesin berupa bensin premium, menyiapkan es. Dalam sekali trip melaut menghabiskan $10-15$ bensin premium sesuai jarak tempuh melaut dan untuk es menghabiskan 1 balok es.

c. Setting alat tangkap

Proses setting alat tangkap dilakukan di daerah yang telah direncakanan seperti daerah kendari dan buton dengan alokasi waktu dari tebar pancing hingga penarikkan pancing \pm 3 jam . d. Penanganan Hasil (Haulling)

Penanganan hasil dilakukan setelah penarikan pancing. Kegiatan ini meliputi sortir hasil tangkapan dan penyimpanan hasil tangkapan pada box menggunakan es. Penanganan hasil ini dilakukan untuk menjaga kualitas dan mutu ikan.

Kegiatan pengolahan di Kecamatan Nambo adalah pengolahan bakso ikan tuna, jenis pengolahan ini yang paling banyak diminati oleh konsumen. Berikut adalah tahapan usaha pengolahan bakso ikan tuna:

a. Persiapan bahan baku

Bahan baku yang didapat, didapatkan dari pengepul ikan laut di kota kendari. Kemudian untuk bahanbahannya adalah ikan tuna, tepung kanji, bawang putih, lada, garam, minyak goreng, dan air.

b. Pengolahan bahan baku

Proses pengolahan yang dilakukan adalah pengolahan bakso ikan. Langkah pertama yang dilakukan yaitu ikan dibersihkan terlebih dahulu dengan membuang kotorannya sampai bersih kemudian di fillet lalu diambil daging putihnya setelah itu dilakukan pencucian ulang sampai $5 x$ hingga bersih. Penggilingan daging ikan dilakukan menggunakan penggilingan manual, pencampuran bumbu (bawang putih, lada, garam, putihnya telur, tepung kanji ditambah 
es batu dan air secukupnya kemudian diblender). Daging giling dibentuk bulatan dan dimasukkan ke dalam air panas dengan suhu $90^{\circ}$, lalu tunggu sampai olahan bakso tersebut terapung, bila sudah terapung lalu diangkat dan dimasukkan ke dalam baskom jaring-jaring dan tiriskan hingga dingin.

c. Packing

Proses packing bakso ikan tuna dibungkus menggunakan plastik dengan berat perbungus 350 gram setelah itu dilakukan pengepresan menggunakan mesin sealer.

\section{Produksi dan Produktivitas Pembesaran Ikan Kuwe}

Produksi dan produktivitas wadah keramba jaring tancap pembesaran ikan kuwe pada kelompok kerambah tancap di Kelurahan Sambuli dapat dilihat pada Tabel 2. Dari data produktivitas sampel responden yang ada di Kelurahan Sambuli pada tabel di atas didapatkan nilai rata-rata produktivitas $12,56 \mathrm{~kg} / \mathrm{m}^{2}$.

\section{Analisa Masalah Perikanan}

Berdasarkan hasil identifikasi dan pengamatan permasalahan yang telah di identifikasi dan diamati menggunakan metode analisa SWOT dapat dilihat pada Tabel 5.

\section{Sistem Penyuluhan Perikanan}

Kegiatan penyuluhan perikanan di Kota Kendari berada dalam naungan Dinas Kelautan Dan Perikanan (DKP) Kota Kendari. DKP Kota Kendari mengkoordinir kegiatan penyuluhan

Tabel 2. Produksi dan Produktifitas Pembesaran Ikan pada Kelompok Keramba Tancap

\begin{tabular}{lccccccc}
\hline $\begin{array}{l}\text { Nama pelaku } \\
\text { utama / RTP }\end{array}$ & $\begin{array}{c}\text { Luas } \\
\text { lahan } \\
\left(\mathbf{m}^{2}\right)\end{array}$ & $\mathbf{N t}_{1}$ (ekor) & $\begin{array}{c}\mathbf{N t}_{2} \\
(\mathbf{e k o r})\end{array}$ & $\mathbf{S R}(\%)$ & $\begin{array}{c}\text { Berat/ekor } \\
(\mathbf{g r})\end{array}$ & $\begin{array}{c}\mathbf{P} \\
(\mathbf{k g})\end{array}$ & $\begin{array}{c}\text { Produktivitas } \\
\left(\mathbf{k g} / \mathbf{m}^{2}\right)\end{array}$ \\
\hline Suludi & 96 & 1500 & 500 & 33 & 1000 & 500 & 5,2 \\
Musdin & 24 & 500 & 350 & 70 & 1000 & 350 & 14,5 \\
Arsan & 96 & 2000 & 800 & 40 & 1000 & 800 & 8,3 \\
Siga & 24 & 600 & 450 & 75 & 1000 & 450 & 18,7 \\
Sahrudi & 48 & 700 & 610 & 87 & 1000 & 610 & 12,7 \\
Amran & 48 & 800 & 670 & 83 & 1000 & 670 & 13,9 \\
Andi & 24 & 400 & 300 & 75 & 1000 & 300 & 12,5 \\
Nasrun & 48 & 1000 & 820 & 82 & 1000 & 820 & 17 \\
Mastira & 24 & 500 & 350 & 70 & 1000 & 350 & 14,5 \\
Rahman & 48 & 500 & 400 & 80 & 1000 & 400 & 8,3 \\
\hline Rata-rata & 850 & 525 & 69,5 & 1000 & 525 & 12,56 & 48 \\
\hline
\end{tabular}


perikanan yang dilaksanakan di setiap kecamatan yang termasuk wilayah kerjanya, pada wilayah Kota Kendari hanya Dinas Kelautan Dan Perikanan saja yang menaungi masalah perikanan baik bidang kelautan, bidang perikanan tangkap, bidang perikanan budidaya, bidang usaha perikanan dan bidang unit pelaksana teknis tempat pelelangan ikan.
Kecamatan Nambo memiliki dua penyuluh PNS dibidang perikanan. Penyuluh yang ada dalam wilayah kerja Penyuluh memberikan penyuluhan kepada sasaran secara merata dan sudah mampu mengembangkan usaha dibidang perikanan baik pembesaran ikan, penangkapan ikan dan pengolahan maupun pemasaran. Daftar penyuluh perikanan Kecamatan Nambo bisa dilihat pada Tabel 3.

Tabel 3 Diagram Matrik SWOT

\begin{tabular}{|c|c|c|}
\hline IFAS & Kekuatan (S) & Kelemahan (W) \\
\hline EFAS & $\begin{array}{l}\text { Nelayan sudah memiliki } \\
\text { pengalaman melaut selama } 2 \\
\text { tahun. } \\
\text { Teknologi penangkapan ikan } \\
\text { yang dipakai sudah cukup baik } \\
\text { Tingkat pendapatan nelayan } \\
\text { berbeda di tiap daerah. } \\
\text { Harga Jual ikan tergantung } \\
\text { kualitas } \\
\text { Kelompok sudah terbentuk }\end{array}$ & $\begin{array}{l}\text { Kurangnya akses permodalan. } \\
\text { Kualitas ikan hasil tangkapan } \\
\text { masih belum memenuhi kriteria. } \\
\text { Kurangnya sarana prasarana } \\
\text { pendukung kegiatan } \\
\text { penangkapan ikan } \\
\text { Berkurangnya hasil tangkapan. } \\
\text { Fungsi kelompok belum baik }\end{array}$ \\
\hline Peluang (O) & Strategi S-O & Strategi W-O \\
\hline $\begin{array}{l}\text { Adanya dukungan dari } \\
\text { pemerintah daerah maupun } \\
\text { pusat } \\
\text { Potensi sumberdaya ikan di } \\
\text { perairan kota kendari cukup } \\
\text { besar. } \\
\text { Permintaan pasar dari hasil } \\
\text { tangkapan cukup besar dan } \\
\text { merupakan ikan ekonomis } \\
\text { penting. } \\
\text { Adanya pasar ikan. } \\
\text { Tersedia nya layanan penunjang }\end{array}$ & $\begin{array}{l}\text { Kemudahan fasilitasi perijinan } \\
\text { nelayan untuk melaut. } \\
\text { Penerapan teknologi } \\
\text { penangkapan ikan sebagai } \\
\text { peningkatan kualitas produk hasi } \\
\text { tangkapan . } \\
\text { penangkapan ikan sebagai } \\
\text { upaya peningkatan ekonomi } \\
\text { sekaligus pelestarian } \\
\text { sumberdaya ikan } \\
\text { Meningkatkan hasil produksi }\end{array}$ & $\begin{array}{l}\text { Memberikan informasi tentang } \\
\text { ada nya bantuan permodalan. } \\
\text { Melakukan pembinaan terhadap } \\
\text { nelayan untuk meningkatkan } \\
\text { I pengetahuan dan kemampuan. } \\
\text { Memberikan alat teknologi } \\
\text { bantuan dar pemerintah daerah } \\
\text { atau pusat. }\end{array}$ \\
\hline $\begin{array}{l}\qquad \text { Ancaman (T) } \\
\text { Cuaca buruk mengakibatkan } \\
\text { nelayan tidak melaut. } \\
\text { Kurangnya pengawasan di } \\
\text { daerah penangkapan } \\
\text { Harga ikan tidak stabil } \\
\text { Ketidaksuaian perijinan melaut } \\
\text { Lahan pasar mahal }\end{array}$ & $\begin{array}{l}\text { Strategi S-T } \\
\text { Optimalisasi pengawasan pada } \\
\text { daerah penangkapan ikan untuk } \\
\text { mengurangi dampak nelayan. } \\
\text { Memberikan sosialisasi kepada } \\
\text { masyarakat tentang perijinan } \\
\text { kapal }\end{array}$ & $\begin{array}{l}\quad \text { Strategi W-T } \\
\text { Penetapan harga jual minimum } \\
\text { maupun maksimum harga beli } \\
\text { ikan menurut jenisnya. } \\
\text { Menjalankan fungsi- fungsi } \\
\text { kelompok }\end{array}$ \\
\hline
\end{tabular}


Tabel 4. Nama Penyuluh di Kecamatan Nambo

\begin{tabular}{|c|c|c|c|}
\hline Nama & Jenis Penyuluh & Bidang Keahlian & Wilayah Binaan \\
\hline St. Bugiana, S.Pi & Penyuluh PNS & $\begin{array}{l}\text { Pengolahan hasil } \\
\text { perikanan }\end{array}$ & Kecamatan Nambo \\
\hline Hasmia, S.Pi & Penyuluh PNS & Penangkapan ikan & Kecamatan Nambo \\
\hline Sri Agustiana T., S.St.Pi & $\begin{array}{l}\text { Penyuluh Perikanan } \\
\text { Bantu(PPB }\end{array}$ & Penangkapan ikan & Kecamatan Nambo \\
\hline Resky Dwi A., S.Tr.Pi & $\begin{array}{l}\text { Penyuluh Perikanan } \\
\text { Bantu (PPB) }\end{array}$ & Penangkapan ikan & Kecamatan Nambo \\
\hline Indah Arya H., S.Tr.Pi & $\begin{array}{l}\text { Penyuluh Perikanan } \\
\text { Bantu (PPB) }\end{array}$ & Budidaya & Kecamatan Nambo \\
\hline
\end{tabular}

\section{Penyelenggaraan Penyuluhan}

Perencanaan Penyuluhan

Perencanaan kegiatan penyuluhan perikanan yang dilakukan oleh penyuluh di Kecamatan Nambo berdasarkan pada kebutuhan dan masalah yang dihadapi oleh pembudidaya dan nelayan yang dapat diketahui dengan observasi dan wawancara. Obervasi dilakukan dengan cara melakukan kunjungan pada lokasi usaha yang dijalankan oleh sasaran, kemudian mengamati masalah yang ada di lokasi usaha, baik dari segi teknis maupun manajerialnya. Wawancara dilakukan secara langsung kepada sasaran penyuluhan terkait dengan masalah yang dialaminya dalam melaksanakan usaha budidaya dan kebutuhan materi atau teknologi untuk mengembangkan usaha budidayanya. Setelah masalah dan kebutuhan sasaran di inventarisir, selanjutnya ditentukan solusi pemecahannya atau materi yang sesuai dengan masalah dan kebutuhan dari sasaran tersebut.

\section{Pelaksanaan Penyuluhan}

Pelaksanaan penyuluhan di Kecamatan Nambo dilaksanakan dengan sistem kunjungan usaha, dan pertemuan umum, yaitu penyuluh melakukan kunjungan usaha setiap minggu satu kali ke kelompok perikanan, dan pertemuan umum (rapat) setiap bulannya dengan semua penyuluh perikanan di Dinas Kelautan dan Perikanan Kota Kendari.

Materi penyuluhan yang dibuat dan disampaikan sesuai berdasarkan dengan kebutuhan dan permasalahan yang dihadapi oleh pelaku utama (secara partisipatif). Secara umum materi penyuluhan mencakup aspek teknologi, manajemen, ekonomi, ekologis, hukum, sosial dan budaya. Metode penyuluhan merupakan cara atau teknik penyampaian materi penyuluhan oleh para penyuluh kepada 
para petani beserta keluarganya baik secara langsung maupun tidak langsung agar mereka tahu, mau dan mampu menerapkan inovasi (teknologi baru). Metode penyuluhan di Kecamatan Nambo Kota Kendari dipilih berdasarkan sasaran, tujuan, materi, waktu, sarana dan biaya yang tersedia. Metode penyuluhan yang digunakan meliputi metode pendekatan kelompok dan metode pendekatan individu.

Analisis Penentuan Metode dan Media Penyuluhan Penentuan metode dan media penyuluhan bagi pelaku usaha dan pelaku utama di Kecamatan Nambo dilakukan berdasarkan pada beberapa faktor, yaitu faktor sasaran, sumberdaya penyuluhan, keadaan daerah dan kebijaksanaan pemerintah. Untuk sasaran dinilai dari tingkat pengetahuan, sikap, dan keterampilan sasaran, sosial budaya dan jumlah sasaran. Pada sumberdaya penyuluhan dinilai dari kemampuan penyuluh, materi penyuluhan, sarana dan biaya penyuluhan. Keadaan daerah dinilai dengan musim, keadaan usaha tani, keadaan lapangan.

Tingkat adopsi inovasi pelaku usaha dan pelaku utama di Kecamatan Nambo, berada pada tahapan mencoba dan menerapkan, sehingga metode yang tepat diberikan adalah metode pendekatan secara berkelompok. Sedangkan media yang diberikan dapat berupa pemberian media tercetak, karena pelaku usaha tidak ada yang buta huruf dan akses informasi telah dapat dilakukan dengan mudah. Permasalahan dalam kegiatan penyuluhan yang diselenggarakan yaitu: belum memiliki media penyuluhan sebagai penunjang kegiatan penyuluhan, informasi teknologi produksi tepat guna masih kurang dan sulitnya mengumpulkan pembudidaya perikanan dengan lengkap.

\section{Evaluasi}

Untuk mengetahui sejauh mana keberhasilan penyelenggaraan penyuluhan yang dilaksanakan, perlu dilakukan evaluasi untuk setiap jenis kegiatan penyuluhan yang dilakukan. Evaluasi kegiatan ceramah diskusi dan anjang sana yaitu dengan melihat sejauh mana sasaran menerapkan materi yang disampaikan pada usaha yang dijalankannya. Evaluasi atas kinerja penyuluh dilakukan setiap 1 bulan, yaitu dengan mengadakan rapat atau pertemuan rutin. Pertemuan tersebut dihadiri oleh kepala Dinas Kelautan dan Perikanan Kota Kendari dan seluruh petugas penyuluh. Dalam pertemuan tersebut dilakukan evaluasi atas kegiatan penyuluhan yang dilakukan para penyuluh serta dibahas juga kegiatan yang akan dilaksanakan kedepannya. Untuk pelaporan atau 
pembuatan laporan dari kegiatan penyuluhan yang dilaksanakan dilakukan setiap 1 bulan sekali.

\section{SIMPULAN DAN SARAN}

\section{Simpulan}

Dari kegiatan Praktek Keahlian di Kecamatan Nambo dapat disimpulkan sebagai berikut :

a. Kondisi wilayah di Kecamatan Nambo kondusif untuk pengembangan kegiatan perikanan karena kondisi potensi sumber daya alam dan sumber daya manusia yang ada mendukung pengembangan perikanan.

b. Sistem penyuluhan perikanan di Kecamatan Nambo belum sepenuhnya sesuai dengan idealnya sebuah sistem penyuluhan, terkait dengan jumlah personal dan sarana prasarana yang ada.

c. Permasalahan yang dihadapi dalam usaha budidaya pembesaran ikan kuwe di kecamatan nambo salah satunya adalah munculnya hama seperti tiram dan kerang-kerangan yang menempel pada jaring sehingga dapat menyebabkan kerusakan pada jaring, sedangkan pada penangkapan ikan yaitu perubahan cuaca yang menimbulkan para nelayan tidak turun.

\section{Saran}

a. Perlu diadakannya penyuluhan untuk menumbuhkembangkan potensi perikanan yang ada.

b. Perlu diadakannnya kegiatan penyuluhan perikanan yang berjalan dengan baik sehingga penyampaian materi atau informasi dari penyuluh cepat serta permasalahanpermasalahan yang dihadapi pelaku utama akan cepat terselesaikan dengan adanya penyuluhan perikanan.

c. Perlu dikembangkan terobosan teknologi yang mendukung keberhasilan budidaya. Sehingga usaha perikanan dapat menghasilkan keuntungan yang optimal.

\section{DAFTAR PUSTAKA}

Amanah S. 2003. Perencanaan program penyuluhan perikanan dari Desa Anturan, Buleleng, Bali. Bul. Ekon. Perikan. V(1):1-20.

Dhakidae, D. 2005. Profil Daerah Kabupaten dan Kota. Jakarta: PT Kompas Media Nusantara.

Kementerian kelautan dan perikanan. 2012. Peraturan Menteri Kelautan dan Perikanan No. 14 Tahun 2012 Tentang Penumbuhan Kelembagaan Pelaku Utama. Jakarta.

Kementerian-PPN/Bappenas. 2016. Ringkasan: Kajian strategi 
industrialisasi perikanan untuk mendukung pembangunan ekonomi wilayah. Direktorat Kelautan dan Perikanan Kedeputian Bidang Kemaritiman dan Sumber Daya Alam BAPPENAS.

Laksana F. 2008. Manajemen Pemasaran (Pendekatan Praktis). Graha IImu. Yogyakarta

Nuraeni dkk. 2002. Diktat Manajemen Agribisnis. Sekolah Tinggi Penyuluhan Pertanian Bogor. Bogor

Peraturan Menteri Kelautan dan Perikanan No 13 Tahun 2011 Tentang Pedoman Penyusunan Programa Penyuluh Perikanan. Kementerian Kelautan dan Perikanan. Jakarta.

Praptokardyo K, Wellem M. 2012. Manajemen Produksi Operasi Budidaya Perairan. Bogor.

Pusat Pelatihan dan Penyuluhan Kelautan dan Perikanan. 2018. Pedoman kerja penyuluhan perikansan tahun 2018. Kementerian Kelautan Dan perikanan badan riset dan sumber Daya Manusia Kelautan Dan Perikanan Pusat Pelatihan Dan Penyuluhan Kelautan Dan Perikanan. Jakarta.
Rahardi, F; Regina ; dan Nazaruddin. 2008. Jilid 2. Agribisnis Perikanan. Penebar Swadaya. Jakarta

Suryabrata, S. 2012. Metodologi Penelitian. Rajawali Pers. Jakarta Tangke U. 2010. Analisis potensi dan tingkat pemanfaatan sumberdaya

Ikan Kuwe (Carangidae sp.) Di Perairan. J. Ilm. Agribisnis Dan Perikan. 3(Oktober):31-38.

Widodo, U. 2005. Manajemen Usaha Perikanan. Pusat Pengembangan SDM Kelautan dan Perikanan. Departemen Kelautan dan Perikanan. Jakarta. 